\title{
Etnobotani Meniran Hijau (Phyllanthus Ninuri L) Sebagai Potensi Obat Kayap Ular (Herpes Zoster) dalam Tradisi Suku Dayak Ngaju
}

\author{
Maharani Nida Ervina ${ }^{1^{*}}$ dan Yatin Mulyono ${ }^{2}$ \\ ${ }^{1}$ Prodi Tadris Biologi, IAIN Palangka Raya, Palangka Raya, Indonesia 73112, Indonesia \\ *raninida09@gmail.com
}

\begin{abstract}
Abstrak
Tujan penelitian ini mendeskripsikan botani tanaman meniran hijau (Phyllanthus ninuri L), mengetahui kandungan fitokimia dan khasiatnya dalam tradisi pengobatan penyakit herpes zozter oleh masyarakat suku Dayak Ngaju Kalimantan Tengah. Jenis penelitian ini adalah deskriptif eksploratif dengan wawancara dan observasi. Wawancara dilakukan secara terstruktur dan semi terstruktur yang disertai dengan keterlibatan aktif peneliti dalam kegiatan masyarakat setempat / parcipatory ethnobotanica apraisa (PEA). Data tradisi pengobatan suku Dayak Ngaju dan kandungan fitokimia dianalisis deskriptif kualitatif, dan pengaruhnya terhadap kulit dengan membandingkan dengan referensi. Teknik keabsahan data dengan triangulasi / konfirmabilitas, dimana data diambil lebih dari 3 subjek informasi kunci dan non kunci yang berbeda. Hasil penelitian menunjukkan bahwa ekstrak daun meniran hijau dibuat ramuan dicampurkan dengan kasai tai handalai (kotoran cacing tanah) dipercaya mampu menyembuhkan penyakit kulit kayap ular (herpes zoster) dengan metode penggunaan sebagai obat luar serupa salep. Terdapat beberapa perlakuan khas menurut tradisi setempat, yaitu (1) pembuatan ramuan harus dilaksanakan menjelang senja, (2) ada doa tertentu saat pengobatan, (3) pengobatan selama 3 hari berturut-turut dan harus dimulai dari hari jumat, (4) pasien diharuskan membawa jarum. Kandungan ekstrak meniran hijau memiliki kontribusi besar dalam campuran racikan kasai tai handalai. Antrakuinon yang terkandung pada ekstrak meniran membantu merangsang meningkatnya imunitas tubuh dengan mendorong limfosit $\mathrm{T}$ aktif bekerja, zat quercetin berperan sebagai anti-inflamasi, dan kandungan alkaloid pada meniran berperan sebagai anti-nociceptive. Kotoran cacing mengandung mineral berupa Zinc ( $\mathrm{Zn})$ yang juga memiliki peran besar dalam penyembuhan herpes zoster serta menutrisi kulit.
\end{abstract}

Katakunci: etnobotani, meniran hijau, herpes zozter

\section{Pendahuluan}

Etnobotani merupakan ilmu kajian yang penting dalam kaitannya dengan sejarah pemanfaatan tumbuhan, bercocok tanam serta proses domestikasi. Menurut Walujo (2017) ${ }^{1}$ disiplin ilmu etnobotani penting untuk dikembangkan karena dengan penelitian etnobotani, didapatkan pemahaman tentang keberhasilan ataupun kekeliruan masyarakat tradisional dalam memahami lingkungannya, sehingga dapat menghindari kesalahan yang sama pada masa sekarang atau masa yang akan datang. Tumbuhan asli Indonesian sangat beragam dan berpotensi memberikan kontribusi terhadap dunia pengobatan. Menurut Nugraha $(2016)^{2}$ tumbuhan asli Indonesia memberikan kontribusi yang besar terhadap produksi obat di dunia, contoh dari 45 macam produksi obat penting di Amerika dari obat tropika, ada 14 spesies yang berasal dari Indonesia.

Indonesia memiliki budaya yang beranekaragam sesuai dengan adat-istiadat di daerahnya masing-masing. Masyarakat tradisional di Indonesia telah menggunakan berbagai ramuan herbal tradisional secara turun temurun. Salah satunya adalah budaya Masyarakat suku Dayak Ngaju (Kalimantan Tengah) telah menemukan metode pengobatan untuk penyakit Herpes zoster dengan meracik salap berbahan herbal tumbuhan meniran (Phyllanthus urinaria) dengan campurancampuran benda padat atau semipadat berupa tanah dan kotoran cacing diiringi pelafalan mantra tertentu hingga menghasilkan sebuah produk yang disebut kasai tai handalai. Penemuan ini merupakan bukti adanya kearifan lokal berupa etnofarmakologi. Hingga saat ini kasai tai handalai merpakan jenis salap racikan yang diajarkan dan digunakan secara turun-temurun. Kasai tai 
handalai terkenal sangat ampuh untuk mengobati Herpes zoster hanya dalam waktu kurang lebih 3 hari sejak munculnya lesi kulit. Pengobatan ini masih sangat populer di kalangan masyarakat suku Dayak Ngaju namun belum pernah terekspos media. Mengingat adanya bukti keberhasilan serta testimoni maka menarik dan perlu diadakannya penyelidikan serta penelitian mengenai kandungan serta khasiat kasai tai handalai dalam pengobatan Herpes zozter.

Suku Dayak Ngaju merupakan suku yang paling besar dibandingkan dengan suku lainnya yang ada di Kalimantan Tengah. (Setyowati, 2005: 504) ${ }^{3}$. Suku Dayak Ngaju berasal dari penduduk Austronesia yang melakukan migrasi 4500 tahun silam ke Filipina hingga menuju kepulauan Indonesia dan menetap di pulau Kalimantan. (Harysakti A., dkk. 2017: 72) . Masyarakat suku Dayak Ngaju di Kalimantan Tengah pada kesehariannya masih memanfaatkan tumbuhan dalam kehidupan. Baik untuk memenuhi kebutuhan di bidang sandang, pangan, maupun papan. Dibidang pengobatan penggunaan tanaman juga masih dipraktekkan meski sudah tersedia lembaga pelayanan kesehatan seperti puskesmas. (Setyowati, 2005: 505) ${ }^{3}$. Pengolahan tumbuhan herbal sebagai obat oleh masyarakat Suku Dayak Ngaju masih dilakukan secara tradisional. Adapun pengolahannya meliputi beberapa tahap seperti pengidentifikasian jenis tanaman herbal, waktu pengumpulan, penyortiran, pencucian, pengeringan, dan teknik pengolahan. Teknik pegolahan tanaman herbal oleh masyarakat secara sederhana biasanya dengan perebusan, penyeduhan, dan pembuatan serbuk instan. (Purwanto, B., 2016: 24-28). ${ }^{5}$

\section{Metode}

Jenis penelitian ini adalah deskriptif eksploratif dengan wawancara dan observasi. Wawancara dilakukan secara terstruktur dan semi terstruktur yang disertai dengan keterlibatan aktif peneliti dalam kegiatan masyarakat setempat / parcipatory ethnobotanica apraisa (PEA). Data tradisi pengobatan suku Dayak Ngaju dan kandungan fitokimia dianalisis deskriptif kualitatif, dan pengaruhnya terhadap kulit dengan membandingkan dengan referensi. Teknik keabsahan data dengan triangulasi / konfirmabilitas, dimana data diambil lebih dari 3 subjek informasi kunci dan non kunci yang berbeda.

\section{Hasil dan Pembahasan}

Meniran merupakan tumbuhan genus Phylanthus (Euphorbiaceae) dengan 750-800 spesies yang dapat dijumpai di daerah tropis maupun subtropis. Beberapa spesies dari tumbuhan ini telah memberi kontribusi besar pada dunia kedokteran. Salah satu spesiesnya yaitu Phylanthus niruri Linn. (Alegantina, 2015: 12). ${ }^{6}$ Meniran hijau (Phyllanthus niruri L) merupakan tumbuhan terna liar, berasal dari Asia dan kini telah hingga Benua Afrika, Australia, dan Amerika. (Kardinan, 2004: 6). ${ }^{7}$

Meniran hijau (Phyllanthus niruri L) dapat hidup di daratan mana saja baik di tempat berbatu, tempat lembab seperti di sepanjang saluran air, ataupun di antara rumput dan semaksemak. Meniran hijau juga tumbuh di dataran tinggi hingga ketinggian $1000 \mathrm{~m}$ dpl. (Dalimarta, 2002 dalam Rivai, 2013: 15). ${ }^{8}$

Di Indonesia, penyebaran meniran cukup luas. Hal itu diketahui dari beberapa nama daerah yang melekat pada tumbuhan ini, seperti Uru Handalai (Dayak Ngaju).

Berikut ini adalah klasifikasi dari tumbuhan meniran (Phyllanthus niruri L):

Regnum : Plantae

Divisi : Spermatophyta

Kelas : Dicotyledoneae

Ordo : Euphorbiales

Famili : Euphorbiaceae

Genus : Phyllanthus

Spesies : : Phyllanthus niruri L. 
(Kardinan, 2004: 7). ${ }^{7}$ Meniran hijau (Phyllanthus niruri L.) memiliki batang berwarna hijau muda atau hijau tua. Setiap cabang atau rantingnya terdiri dari 8-25 helai daun. Daun berwarna hijau. Ukurannya 0,5-2 x 0,25-0,5 cm. (Kardinan, 2004: 11). ${ }^{7}$ Meniran hijau (Phyllanthus niruri L.) mempunyai bunga jantan dan betina berwarna putih. Bunga jantan keluar dari bawah ketiak daun sedangkan bunga betinanya keluar di atas ketiak daun. (BPPP, 2009: 29). Kepala sari meniran hijau yang sudah matang akan pecah secara membujur. (Kardinan, 2004: 11). ${ }^{7}$ Gambar meniran hijau dan bunganya ditunjukkan pada Gambar 1 .

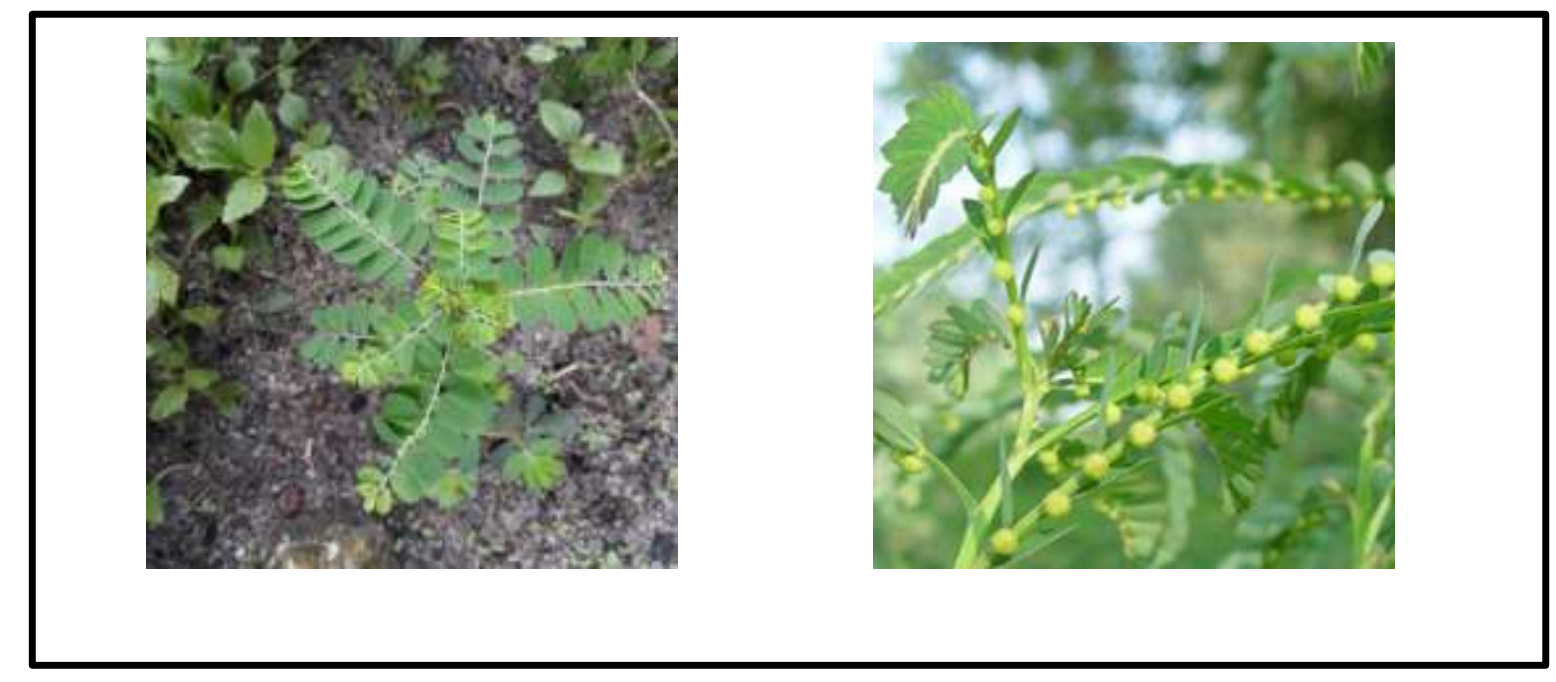

Gambar 1. (a) Tumbuhan Meniran Hijau (Phyllanthus niruri Linn); (b) Bunga Meniran Hijau di Ketiak Daun

\section{Etnobotani Linguistik Meniran Hijau}

Phyllanthus niruri L. merupakan sebutan ilmiah dari tumbuhan meniran hijau dalam taksonomi formal. Di Indonesia tumbuhan ini memiliki banyak sebutan bergantung pada etnis tertentu, misalnya Uru Handalai (Dayak Ngaju). Meniran Hijau (Indonesia). Sejak dahulu telah dikenal dua jenis pengklasifikasian makhluk hidup, yaitu klasifikasi rakyat dan klasifikasi normal. Klasifikasi normal umumnya menggunakan taksonomi ilmiah. Sedangkan klasifikasi rakyat menggunakan bahasa suatu etnis tertentu dan menurut La Hisa $(2016)^{9}$, pengelompokan atau pengklasifikasian oleh rakyat disandarkan melalui 3 elemen, yaitu (1) klasifikasi berdasarkan bentuk, (2) klasifikasi berdasarkan sebutan umum, (3) klasifikasi berdasarkan sebutan spesifik.

Kemampuan mengklasifikasi oleh rakyat didasari oleh adanya keahlian masyarakat dalam memahami karakteristik sesuatu, mengelompokkan, dan membeda-bedakan secara otodidak. Sehingga masyarakat memiliki keahlian dalam membedakan jenis tumbuhkan bahkan beserta variasi tiap jenis tumbuhan hingga akhirnya muncullah sebutan-sebutan berbeda untuk tiap spesies tumbuhan. Mayarakat Suku Dayak Ngaju menyebut tumbuhan Phyllanthus niruri L. (meniran) dengan sebutan Uru Handalai. Menurut bahasa Dayak sendiri Uru diartikan sebagai tumbuhan pendek atau rumput, sedangkan Handalai artinya cacing. Berdasarkan hasil wawancara, meniran hijau oleh masyarakat suku Dayak Ngaju disebut uru sebab berukuran hanya setinggi rumput dan sering dijumpai tumbuh di dekat rerumputan. Sedangkan handalai yang berarti cacing juga menjadi sebutan untuk tumbuhan meniran hijau, alasannya bahwa di tanah yang ditumbuhi meniran hijau akan selalu banyak cacing. Itulah sebab mengapa meniran hijau di sebut uru handalai (rumput cacing). Secara spesifik uru handalai juga disebut lebih lengkap dengan sebutan uru handalai bahandang (merah) atau bahijau (hijau). Sebutan ini didasari oleh warna dari batang tumbuhan meniran. Meniran hijau memberi warna hijau pada seluruh bagiannya. Sedangkan meniran merah batangnya memiliki sedikit warna merah yang dikenal dengan Phyllanthus urinaria. 
Klasifikasi Berdasarkan Bentuk

\section{Uru}

Klasifikasi Berdasarkan Sebutan Umum

\section{Handalai}

Klasifikasi Berdasarkan Sebutan Spesifik

\section{Bahijau}

Bahandang

Gambar 2. Klasifikasi Meniran Hijau

\section{Kandungan Fitokimia Meniran Hijau}

Kandungan fitokimia tumbuhan meniran hijau (Phyllanthus niruri L) antara lain diperoleh dari hasil uji organoleptik ditunjukkan pada Tabel 1.

Tabel 1. Hasil Uji Organoleptik Meniran Hijau (Phyllanthus niruri L)

\begin{tabular}{|c|c|}
\hline Indikator & Hasil \\
\hline Warna & Hijau tua \\
\hline Bau & Khas aromatik \\
\hline Rasa & Pahit \\
\hline
\end{tabular}

Sumber: Jurnal Farmasi Higea 5(2), 2013.

Hasil uji fitokimia, ekstrak meniran hijau (Phyllanthus niruri L.) mengandung flavanoid, steroid, tanin, fenolik, dan saponin. (Rivai, 2013: 18). ${ }^{8}$ Hasil identifikasi kimia ekstrak meniran hijau ditunjukkan pada Tabel 2.

Tabel 2. Hasil Identifikasi Kimia Ekstrak Meniran Hijau (Phyllanthus niruri L.)

\begin{tabular}{|c|c|l|}
\hline $\begin{array}{c}\text { Golongan } \\
\text { Senyawa }\end{array}$ & Hasil & \multicolumn{1}{|c|}{ Karakteristik } \\
\hline Alkaloid & + & $\begin{array}{l}\text { Bouchardat: ada endapan cokelat. } \\
\text { Mayer: endapan puth } \\
\text { Dragendroff: endapan merah bata }\end{array}$ \\
\hline Steroid & + & $\begin{array}{l}\text { Salkowiski: timbul warna cokelat } \\
\text { kemerahan }\end{array}$ \\
\hline Flavanoid & + & $\begin{array}{l}\text { Salkowiski: warna kuning pada penambahan } \\
\text { amonia } \\
\text { Fluoresensi: kuning terang }\end{array}$ \\
\hline Fenolik & + & $\begin{array}{l}\text { FeCl } \\
\text { : timbul warna biru kehijauan }\end{array}$ \\
\hline Saponin & + & $\begin{array}{l}\text { Uji busa: timbul banyak busa setelah } \\
\text { pengkocokan }\end{array}$ \\
\hline Tanin & + & $\mathrm{K}_{2} \mathrm{Cr}_{2} \mathrm{O}_{7}$ : endapan putih \\
\hline
\end{tabular}

Sumber: Jurnal Farmasi Higea 5(2), 2013. Dan

Jurnal Ilmu Kefarmasian Indonesia. Vol. 7. 2009. 
Kandungan lainnya yang terdapat pada meniran hijau (Phyllanthus niruri L.) yaitu quercetin, isoquercetin, quercetrin, astragalin, nirurin, dan rutin. Pada akar meniran hijau terdapat senyawa lignan, norsecurinine, securinine, allosecurinine, dan senyawa alkaloid (entnorsecurinine). (Sudarsono dkk., 1996) ${ }^{10}$. Selain itu meniran menunjukkan adanya kandungan minyak atsiri, flavanoid, antrakuinon, alkanoid, arbutin, glikosida, senyawa golongan fenol, dan tannin. (Sudarsono, et al., 1998., dalam Rivai, 2013: 15) ${ }^{8}$. Meniran juga mengandung komponen flavanoid seperti quercetin, niruritenin, rutin pada seluruh batang lignin seperti betasitosterol, triterpen seperti lupeol asetat, hipofilantin, dan filantin (Rivai, 2013: 15). ${ }^{8}$

\section{Cara Masyarakat Suku Dayak Ngaju Mengolah Meniran Hijau}

Masyarakat suku Dayak Ngaju mengolah meniran hijau sebagai obat herpes zoster dengan menjadikannya obat oles. Obat oleh ini dibuat secara tradisional dengan campuran unik berbahan dasar meniran hijau. Obat ini diolah dan digunakan sebagai obat luar serupa salep. Obat ini disebut dengan sebutan kasai tai handalai. Kasai tai handalai berasal dari bahasa Dayak Ngaju yang berarti: kasai $=$ bedak, tai $=$ kotoran; feces, handalai $=$ cacing tanah. Pembuatan kasai tai handalai juga melibatkan kotoran cacing (tai handalai). Kotoran cacing tanah yang digunakan umumnya berasal dari cacing tanah jenis Lumbricus rubellus, Lumbricus terrestris, atau cacing tanah genus Pheretima. Cacing tanah jenis ini adalah yang paling mendominasi kehidupan dalam tanah di daerah Kota Palangkaraya Kalimantan Tengah pada area non gambut. Sedangkan pada area lahan gambut ditemui tiga jenis cacing tanah, yaitu spesies Dichogaster sp., Pontoscolex corethrurus, dan Megascoiex sp. Pada lahan gambut yang tebal hanya dijumpai Dichogaster saja. Cacing tanah yang dominan di lahan gambut baik di musim kemarau atau musim hujan ialah Pontoscolex corethrurus. Cacing jenis ini tergolong dalam tipe cacing aneksik (Maftu'ah, 2009: 372). ${ }^{11}$

Kotoran cacing tanah yang digunakan oleh masyarakat suku Dayak Ngaju dalam pembuatan kasai tai handalai hanya dari kotoran cacing tanah area non gambut yang ada disekitaran tumbuhan meniran. Proses pembuatan kasai tai handalai dengan ekstrak meniran hijau tidak membutuhkan waktu lama hingga berhari-hari. Pembuatan racikan dilakukan secara konvensional. Adapun bahan pokok yang diperlukan dalam pembuatan kasai tai handalai ialah kotoran cacing yang ada di sekitar tumbuhan meniran hijau dan juga tumbuhan meniran hijau tersebut.

Pada proses pembuatan kasai tai handalai meniran hijau ada beberapa syarat yang harus diperhatikan, yaitu (1) hanya dibuat di hari jum'at, (2) hanya boleh digunakan dari hari jum'at dan pemakaian tidak boleh terputus selama 3 hari, (3) memberikan jarum sebagai prasyarat yang harus dipenuhi oleh orang yang minta diobati kepada si peracik obat, (4) kotoran cacing yang diambil ialah kotoran cacing yang ada di sekitar tumbuhan meniran hijau yang diambil.

Adapun prosedur kerja pembuatan kasai tai handalai dengan ekstrak meniran hijau ini.

1. Menyiapkan alat dan bahan yang diperlukan, seperti ditunjukkan pada Tabel 3.

Tabel 3. Alat dan Bahan Kasai Tai Handalai Dengan Ekstrak Meniran Hijau

\begin{tabular}{|c|c|c|c|c|}
\hline No & Nama Alat & Jumlah & Nama Bahan & Jumlah \\
\hline 1. & Lesung & 1 buah & $\begin{array}{c}\text { Kotoran cacing } \\
\text { (tai handalai) }\end{array}$ & Seperlunya \\
\hline 2. & Penumbuk & 1 buah & $\begin{array}{c}\text { Tumbuhan } \\
\text { meniran hijau }\end{array}$ & Seperlunya \\
\hline 3. & Piring kecil & 1 buah & Jarum & 1 Buah \\
\hline
\end{tabular}

2. Membersihkan tumbuhan meniran hijau dengan cara mencucinya hingga bersih menggunakan air yang mengalir.

3. Mengeliminasi daun meniran hijau dan bagian tumbuhan lainnya yang layu dan diambil seperlunya saja. 
4. Memasukan tumbuhan yang telah dibersihkan dan disortir ke dalam lesung.

5. Memasukkan kotoran cacing tanah(tai handalai) ke dalam lesung.

6. Menumbuk semua campuran tadi dengan penumbuk hingga halus.

7. Menggunakan cairan kental yang dihasilkan dari bahan-bahan yang telah dihaluskan untuk dijadikan salep.

8. Ampas boleh tidak dibuang agar salap tidak lekas mengering.

Adapun cara penggunaan kasai (salep) tai handalai dengan ekstrak meniran hijau ini adalah.

1. Meletakkan jarum di atas piring dimana salep di simpan

2. Mengoleskan salep dengan menyebut mantra-mantra. (Mantra dirahasiakan. Hanya orang Dayak yang boleh tahu).

3. Kasai tai handalai dengan ekstrak meniran hijau hanya dioleskan pada bagian yang luka atau ruam.

4. Pemakaian dimulai pada hari Jum'at dan harus berturut-turut selama 3 hari jangan sampai terputus.

\section{Khasiat Meniran Hijau Terhadap Penyembuhan Penyakit Herpes Zoster}

Hasil wawancara dan testimoni yang diperoleh, pemberian kasai tai handalai dengan ekstrak meniran hijau pada luka luar penyakit Herpes Zoster memberi pengaruh positif. Pengolesan kasai tai handalai dengan ekstrak meniran hijau mampu mengurangi ruam eritematosa, meredakan radang, pengeringan pustula, dan meredakan parestesia. Beberapa senyawa kimia dalam meniran hijau yang berkontribusi dalam penyembuhan penyakit herpes zoster yaitu (1) quercetin, (2) alkaloid, dan (3) antrakuinon.

Quercetin merupakan senyawa golongan flavanoid jenis flavonol. Flavanoid memiliki peran sebagai antimikroba dan antivirus. (Robinson, 1995: 191). ${ }^{12}$ Flavanoid juga memiliki fungsi sebagai antioksidan, antiradikal, antitrombotik, dan antiinflamasi. (Winarsi, 2007: 185). ${ }^{13}$ Quercetin sebagai antiradikal yang mampu langsung menangkap radikal bebas. Menurut Robak dan Gryglewski (1988) ${ }^{14}$, quercetin sebagai antiradikal kuat terhadap radikal peroksil, anion superoksida, dan hidroksil. Beberapa penelitian telah dilakukan mengenai quercetin. Menurut Lakhanpal (2007) ${ }^{15}$, senyawa quercetin berpotensi antiinflamasi sebab kemampuan dalam menghambat produksi TNF- $\alpha$. TNF- $\alpha$ berperan dalam mengaktifkan sistem imun selular dan dapat membunuh parasit secara langsung meskipun lemah. Adanya TNF- $\alpha$ memberi efek biologis pengerahan sel imun seperti neutrofil dan monosit ke tempat yang terinfeksi dan segera menyingkirkan mikroba. Aktifitas ini merangsang hipotalamus yang menginduksi panas, beberapa sel imun yang mati bersama virus atau parasit lain biasanya menghasilkan pustula. Quercetin sebagai penghambat produksi TNF- $\alpha$ namun juga memberi kontibusi dalam membasmi virus yang ada. Hal ini menjadi penyebab pada kasus herpes zoster pemberian meniran hijau membuat tidak bertambahnya pustula dan berkurangnya radang. (Robinson, 1995: 191). ${ }^{12}$

Quercetin berperan sebagai anti oksidan, yaitu melawan kerusakan radikal bebas, peradangan dan efek penuaan. Quercetin dapat melawan proses alami "oksidasi" yang terjadi seiring waktu seiring dengan bertambahnya usia. Quercetin dapat membantu menghentikan partikel perusak dalam tubuh atau radikal bebas, yang mengakibatkan gangguan terhadap cara kerja sel, antara lain merusak membran sel, meningkatkan mutasi sel, mengubah cara kerja DNA, dan menyebabkan sel-sel sehat mati. Quercetin merupakan anti-histamin alami dan anti-inflamasi, sehingga efektif untuk menurunkan efek alergi musiman dan makanan secara alami, plus asma dan reaksi kulit. Histamin adalah zat kimia yang dilepaskan ketika sistem kekebalan mendeteksi alergi atau sensitivitas, histamin akan dilepaskan sehingga dapat mencegah terjadinya reaksi alergi. Quercetin berperan membantu agar pelepasan histamin dari sel-sel kekebalan tertentu menjadi stabil. Quercetin juga dapat membantu melindungi kulit dari efek gangguan seperti fotosensitifitas dan dermatitis. Quercetin memblokir pelepasan banyak sitokin pro-inflamasi, 
seperti IL-8 dan TNF, sehingga membantu menghentikan gejala yang berkaitan dengan peradangan kulit, bahkan pada orang yang tidak menemukan bantuan dari pengobatan atau resep konvensional lainnya. Aprilina, Nastiti, Putriandani, \& Hestiningsih (2012) ${ }^{16}$; Hadiansyah $(2017)^{17}$; dan Ventiyaningsih, Lizafni, \& Rahmi, $(2016)^{18}$.

Ningrum, Purwanti, \& Sukarsono (2016) ${ }^{19}$ menjelaskan bahwa senyawa alkaloid dapat mengobati infeksi pada kulit dan menyembuhkan bekas luka. Alkaloid sudah lama dikenal dan telah digunakan dalam bidang farmasi bagi manusia. Bagi tumbuhan alkaloid dinyatakan sebagai senyawa yang melindungi tumbuhan dari serangan parasit. (Robinson, 1995: 283). ${ }^{12}$ Alkaloid pada meniran hijau bersifat analgesik atau antinociceptive bagi manusia dan hewan. Aktivitas analgesik dari tumbuhan meniran hijau telah diuji melalui ekstrak daun metanol meniran hijau (Phyllanthus niruri L). (Sijuade, 2016: 4). ${ }^{20}$

Antrakuinon merupakan turunan senyawa kuinon yang memiliki warna. Antrakuinon bersifat antifungus dan antimikrobia. Kandungan antrakuinon pada meniran juga membantu dalam membasmi virus serta meningkatkan kinerja sel T dan sel B. (Kshirsagar, 2014). ${ }^{21}$ Antrakuinon memberi kontribusi dalam penanganan imunosupresi. Meningkatnya imunitas tubuh memberi efek dalam merespon patogen seperti virus Varicella zoster. Virus Varicella zoster yang menginfeksi ganglion sensoris akan merusak serabut saraf serta mengacaukan impuls sehingga tanggapan yang diberikan berupa rasa nyeri. Hilangnya infeksius akan mempercepat pemulihan sel saraf, terutama serabut saraf pada kulit penderita herpes zoster. Sehingga pemberian meniran hijau pada lesi kulit dapat membuat kurangnya rasa nyeri.

\section{Kontribusi Kotoran Cacing Tanah dalam Pengobatan Herpes Zoster}

Kotoran cacing tanah turut memberi kontibusi dalam tradisi pengobatan herpes zoster oleh masyarakat Suku Dayak Ngaju. Kotoran cacing tanah yang digunakan ialah kotoran cacing yang terdapat dipermukaan tanah di sekitar tumbuhan meniran diambil. Adapun kotoran cacing yang diambil berasal dari jenis cacing Lumbricus atau Pheretima. Cacing Lumbricus dan Pheretima merupakan jenis cacing non gambut yang hidup memakan limbah organik dari tumbuhan maupun hewan (Maftu'ah, 2009). ${ }^{11}$ Kandungan nutrisi dan mineral dari kotoran cacing pemakan limbah organik dari tumbuhan maupun hewan ditunjukkan pada Tabel 4.

Tabel 4. Kandungan Nutrisi Dan Mineral Dari Kotoran Cacing

\begin{tabular}{|c|c|}
\hline Kandungan & Kadar \\
\hline $\mathrm{C}$ total & $10,1 \%$ \\
\hline $\mathrm{N}$ total & $1,182 \%$ \\
\hline $\mathrm{P}$ total & $456 \mathrm{ppm}$ \\
\hline $\mathrm{K}$ total & $1,504 \%$ \\
\hline $\mathrm{Ca}$ total & $0,208 \%$ \\
\hline $\mathrm{Mg}$ total & $0,408 \%$ \\
\hline $\mathrm{Zn}$ total & $174 \mathrm{ppm}$ \\
\hline $\mathrm{Mn}$ & $1610 \mathrm{ppm}$ \\
\hline $\mathrm{Fe}$ & $1,174 \%$ \\
\hline
\end{tabular}

Sumber: Warsana. Dimuat dalam tabloid Sinar Tani, 4 Februari 2009.

Kandungan mineral pada kotoran cacing seperti Zinc ( $\mathrm{Zn}$ ) membantu dalam penyembuhan luka bakar dan luka serta berperan sebagai fungsi kekebalan. Zinc dibutuhkan oleh sel, kulit, dan mukosa saluran cerna. (Widhyari, 2012: 142). ${ }^{22}$

Kendati demikian bagaimanapun juga kotoran cacing tanah tak jarang mengandung Monocystis kelompok Gregarina yang merupakan parasit pada cacing tanah. Biasanya Monocystis banyak dijumpai pada vesikula seminalis cacing tanah. Monocystis, pada pola hidupnya memakan sitoplasma morula sperma pada cacing. Adapun siklus Monocystis pada cacing tanah berawaldari 
termakannya oocyst oleh cacing, oocyst yang masuk ke saluran pencernaan menghasilkan sporozoit yang akan keluar menuju vesikula seminalis. Sporozoit akan tumbuh menjadi tropozoid. Tropozoid dewasa akan melakukan fusi plasma membentuk gametosit yang akan segera mengalamai pembelahan tanpa pembelahan sitoplasma dan menghasilkan banyak gamet. Gametgamet akan membentuk zigot yang kemudian zigot akan membentuk oocyst. Oocyst ini pada akhirnya akan dikeluarkan atau dilepaskan kembali di lingkungan. (Wallace \&Taylor, 1997). ${ }^{23}$

\section{Simpulan}

Meniran hijau (Phyllanthus niruri L) merupakan tanaman berpotensi obat yang digunakan oleh masyarakat Suku Dayak Ngaju sebagai obat herpes zoster. Ekstrak daun meniran hijau dibuat ramuan dicampurkan dengan kasai tai handalai (kotoran cacing tanah) dipercaya mampu menyembuhkan penyakit kulit kayap ular (herpes zoster) dengan metode penggunaan sebagai obat luar serupa salep. Terdapat beberapa perlakuan khas menurut tradisi setempat, yaitu (1) pembuatan ramuan harus dilaksanakan menjelang senja, (2) ada doa tertentu saat pengobatan, (3) pengobatan selama 3 hari berturut-turut dan harus dimulai dari hari jumat, (4) pasien diharuskan membawa jarum. Kandungan ekstrak meniran hijau memiliki kontribusi besar dalam campuran racikan kasai tai handalai. Antrakuinon yang terkandung pada ekstrak meniran membantu merangsang meningkatnya imunitas tubuh dengan mendorong limfosit $\mathrm{T}$ aktif bekerja, zat quercetin berperan sebagai anti-inflamasi, dan kandungan alkaloid pada meniran berperan sebagai anti-nociceptive. Kotoran cacing mengandung mineral berupa Zinc (Zn) yang juga memiliki peran besar dalam penyembuhan herpes zoster serta menutrisi kulit.

\section{Referensi}

[1] Walujo, E. B. (2017). Sumbangan ilmu etnobotani dalam memfasilitasi hubungan manusia dengan tumbuhan dan lingkungannya. Jurnal Biologi Indonesia, 7(2).

[2] Nugraha, D. R. (2016). Kajian Etnobotani Tumbuhan Obat Oleh Masyarakat Di Desa Wangunsari Kabupaten Bandung Barat (Doctoral dissertation, FKIP UNPAS).

[3] Setyowati, F. M. (2005). Etnobotani masyarakat dayak ngaju di daerah timpah kalimantan tengah. Jurnal Teknologi Lingkungan, 6(3).

[4] Harysakti, A., \& Mulyadi, L. (2017). Penelusuran Genius Loci Pada Permukiman Suku Dayak Ngaju Di Kalimantan Tengah. Jurnal Spectra, 12(24), 72-86.

[5] Purwanto, Budhi. (2016). Obat Herbal Adalah Andalan Keluarga. Yogyakarta: Penerbit Flashbook.

[6] Alegantins, S.,dkk. 2015. Pengujian Mutu dan Penetapan Kadar Filantin Pada Ekstrak Etanol Herba Meniran (Phyllanthus niruri Linn). Bul. Peneliti Kesehatan. 43(1).

[7] Kardinan, I. A., \& Kusuma, F. R. (2004). Meniran penambah daya tahan tubuh alami. AgroMedia.

[8] Rivai, H., Refilia S., Agusri, B. (2013). Karakterisasi Ekstrak Herba Meniran (Phyllanthus niruri Linn) dengan Analisa Fluorensi. Jurnal Farmasi Higea, $5(2$.

[9] La Hisa. (2017). Dokumentasi Etnobotani Linguistik Tumbuhan Sagu: Laporan Awal dari Etnis Marori Di Taman Nasional Wasur Merauke. Jurnal Linguistik Indonesia, 35(2).

[10] Sudarsono, P. A., Gunawan, D., Wahyuono, S., Donatus, I. A., \& Drajad, M. (1996). Tumbuhan Obat. Yogyakarta: Pusat Penelitian Obat Tradisional Universitas Gajah Mada.

[11] Maftu'ah, E., \& Susanti, M. A. (2009). Komunitas Cacing Tanah Pada Beberapa Penggunaan Lahan Gambut Di Kalimantan Tengah (Earthworms Community on Several Land Uses of Peat Land in Central Kalimantan). Berita Biologi, 9(4).

[12] Robinson, T. (1995). Kandungan Organik Tumbuhan Tinggi. Bandung: Penerbit ITB.

[13] Winarsi, H. (2007). Antioksidan Alami dan Radikal Bebas. Yogyakarta: Kanisius. 
[14] Robak, J., Gryglewski. (1988). Flavanoids are Scavengers of Superoxide Anions. Biochemical Pharmacology, 37(5).

[15] Lakhanpal, P., \& Rai, D. K. (2007). Quercetin: a versatile flavonoid. Internet Journal of Medical Update, 2(2), 22-37.

[16] Aprilina, M. S., Nastiti, D. P., Putriandani, A. D., \& Hestiningsih, R. (2012). Metode plester herbal berbahan bunga teratai (Nelumbium nelumbo Druce) bagi penderita impetigo. Jurnal Ilmiah Mahasiswa, 2(2).

[17] Hadiansyah, F. (2017). Pengaruh Jenis Pelarut Dan Jenis Teh (Camellia sinensis L) TERHADAP Kandungan Senyawa Quercetin pada Ekstrak Teh (Doctoral dissertation, Fakultas Teknik).

[18] Ventiyaningsih, A. D. I., Lizafni, Y., Rahmi, Y. (2016). Kadar Quercetin Buah dan Jus Apel Lokal dan Impor Pada Suhu Dingin. Jurnal PRIMORDIA, 12(2).

[19] Ningrum, R., Purwanti, E., Sukarsono. (2016). Identifikasi Senyawa Alkaloid Dari Batang Karamunting (Rhodomyrtus tomentosa) Sebagai Bahan Ajar Biologi Untuk SMA Kelas X. Jurnal Pendidikan Biologi Indonesia, 2: (3) 231-236.

[20] Sijuade, A.O. (2016). In Vivo Evaluation of Analgesic Activities of Phyllanthus niruri Leaf Methanol Extract in Experimental Animal Models. Journal of Advances in Medical and Pharmaceutical Science, 8(3). Article no.JAMPS.26826.

[21] Kshirsagar, A. D., Panchal, P. V., Harle, U. N., Nanda, R. K., \& Shaikh, H. M. (2014). Antiinflammatory and antiarthritic activity of anthraquinone derivatives in rodents. International Journal of Inflammation, 2014. Hisa, L. (2017). Dokumentasi Etnobotani Linguistik Tumbuhan Sagu: Laporan Awal dari Etnis Marori Di Taman Nasional Wasur Merauke. Jurnal Linguistik Indonesia 35(2).

[22] Widhyari, S. D. (2012). Peran dan Dampak Defisiensi Zinc(Zn) Terhadap Sistem Tanggap Kebal. Wartazoa, 22(3).

[23] Wallace, Robert L., dan W. K. Taylor. (1997). Invertebratae Zoology Fifth Edition. New Jersey: Prentice Hall Inc. 